\title{
1. EU integration and the welfare state
}

\subsection{THE POLITICISATION OF SOCIAL EUROPE AFTER THE GREAT RECESSION}

With the onslaught of the global financial and economic crisis, the European Union (EU) transformed - overnight and contre coeur - from a benign project of Pareto-optimal single market expansion and currency integration into a highly contested political union. The Greek sovereign debt crisis of 2010 that almost brought down the euro fed back into political distrust among the leaders of the Member States, with the European Commission caught in the middle of the crossfire. Even within the technocratic leadership of the European Central Bank (ECB) discord about Eurozone crisis management flared up for all to see. Yet, the politicisation of the EU should not be understood as a by-product of the Great Recession. Before the financial crash, middle-class fears of falling behind invoked a narrative of welfare paradise lost, pitted against the globalising ambitions of the EU. In 2005 the French and Dutch electorates rejected the draft EU Constitutional Treaty. The no-vote, especially in France, was strongly influenced by a political uproar over the 'Bolkestein directive' on service liberalisation. It was expected that service firms would relocate to EU Member States with low-quality labour and social protection standards, made possible by the enlargement with 12 new members from Central and Eastern Europe in 2004 and 2007, to undermine the inclusive welfare states of Western Europe. French trade unions emblematically reframed the Bolkestein directive in terms of the 'plombiers Polonai' flooding the internal market.

Evidently, the looming sense of social betrayal by the EU further festered by the track-record of EU Great Recession crisis management. After a brief spell of fire-brigade Keynesian stimulus in 2009, with the European Commission allowing member countries to temporarily relax the budget restrictions prescribed by the 1997 Stability and Growth Pact (SGP), by the spring of 2010, the Greek sovereign debt crisis confronted the EU with a wholly novel fiscal aftershock. As contamination fears spread from Greece to the weaker periphery of the Eurozone, including Spain, Portugal and Ireland, investors turned to speculate against the euro. In an attempt to stave off contagion, the besieged economies turned to intrusive fiscal austerity measures. The financial crisis was redefined as a crisis of fiscal profligacy practically over- 
night, requiring tough and prolonged public austerity. Also, other European governments, especially those that had been forced to bail out systemic banks, such as France, the Netherlands and the UK, staged austerity-oriented welfare reforms, including labour market deregulation, cuts in civil servant salaries, pension benefit freezes, retirement age rises, and retrenchments in social transfers and services. The change of heart from the Keynesian automatic stabilisation and fiscal stimulus momentum of 2008 and 2009 to austerity was symbolically sealed by the European Council, with the establishment of a so-called 'European Semester', during which national governments, working to a set tight timetable, were required to put their budgets up for discussion by their peers and the European Commission. In February 2011, codifying the change in mentality, the European Commission published the first Annual Growth Survey (AGS), which identified fiscal profligacy, overregulated labour markets, overgenerous welfare states, excessively strong trade unions, and rigid wage bargaining institutions as key impediments to European growth and competitiveness. By insisting that EU crisis management does 'not require large public investments', the Commission pressed for tightening up of national budgets as the single best strategy for regaining confidence in capital markets. At the summit of 9 December 2011, Eurozone leaders agreed on a 'fiscal compact' to enforce budgetary discipline, backed by automatic sanctions and fines, based on the ordo-liberal German 'rule-based' economic policy legacy of balanced budgets and price stability.

Relentless pressures for deficit reduction, coming from the EU, the ECB and also the International Monetary Fund (IMF) - for Greece, Ireland and Portugal under the supervision of the Troika - in the process, confronted national governments with increasingly disenchanted electorates unwilling to abide by the austerity compromises agreed to by national leaders at the level of the EU. To add insult to injury, austerity-led crisis management took affect against a normative commitment of cohesion and social progress featuring prominently in the EU Treaties, and especially so after the adoption of the Lisbon Treaty, which formally entered into force in January 2009. Here, the Union is conceptualised as a 'social market economy', aimed at full employment and social progress, committed to combatting social exclusion and discrimination and promoting social justice and protection. Alongside some 20 other references to 'solidarity', the Treaties furthermore maintain that - in defining and implementing its policies and activities - the Union shall take into account requirements linked to the promotion of a high level of employment, the guarantee of adequate social protection, the fight against social exclusion, and a high level of education, training and protection of human health.

Unsurprisingly, as of 2010, the EU has been harshly criticised for undermining its social acquis over the Great Recession. A great number of academic observers today refer to the glaring 'social deficit' (Copeland, 2015) in terms 
of 'debasing' (Crespy and Menz, 2015), 'decline' (Graziano and Hartlapp, 2019) and even 'dismantling' (Degryse and Pochet, 2018) Social Europe in hard economic times. The legal scholar Claire Kilpatrick (2018) continues to allude to the 'displacement of Social Europe', referring to mechanisms of dismantling, weakening national social and labour protection systems in the European integration process. In a multifaceted fashion, Wolfgang Streek (2018) argues that an incipient 'progressive regression' of EU social policy has taken root whereby 'European social policy as a political project has disappeared from sight' (p. 16).

The displacement of Social Europe, which occurred in the past decades, contributed to the mounting dissensus towards the Union. By imposing increasing challenges to the institutional foundations of nation states, the new post-crisis economic governance further exacerbated what Ferrera calls the 'sovereignty contest' over the bounding rules that govern social sharing practices and thus define 'who has access to what forms of protection' (Ferrera, 2017a). The clash between nation-based social protection needs and EMU-induced austerity and spending cuts has rapidly escalated and has entered the electoral arena, where it is generating a new, turbulent split between pro- and anti-EU actor coalitions (Hutter and Kriesi, 2019). In this regard, several scholars have focused on the mobilisation of political parties in defence of national welfare states against the 'intrusiveness' of the EU in domestic decision-making and on the heightened politicisation of EU affairs at the domestic level (Hutter et al., 2016; Manow et al., 2018). In many Member States, especially in the so-called debtor countries, the social consequences of the Euro crisis have often been perceived as a cost inflicted by the EU, since most of the austerity measures implemented at the national level have been adopted under the 'shadow of hierarchy' of the new EU economic governance rules (Dawson, 2018).

The increasing centrality of social issues in the European public debate, the rising conflicts between political actors and the mounting dissensus towards the European intrusiveness is the result of what can be called the 'politicisation of Social Europe' (de Wilde and Zürn, 2012). Politicisation as a concept does not apply only to social and employment issues but grasps a broader dynamic that unfolds from a broader tension between the dynamics of EU-building and the preservation of the cultural, redistributive and political capacities of national governments. Such a tension between the EU integration process and national sovereignty spaces has always been latent whenever the former moved beyond its market integration traditional rationale. However, it was only during the last decade that it heightened. In this period, in fact, simultaneous crises (Euro crisis, refugees' crisis, Brexit) have been affecting multiple policy domains, including social and employment policies.

As argued by Genschel and Jachtenfuch (2017), the outbreak of these multiple EU crises significantly increased the functional demand for supra- 
national policy coordination to tackle the problems deriving from Member States' interdependence, integration-related negative externalities and spillover effects. However, by moving beyond traditional market integration rationale and touching on core state powers, such a demand soon collided with the 'tight political constraints on supply' (Genschel and Jachtenfuch, 2017), namely, with the limited competencies of the EU in core state powers and with Member States' lack of willingness to cede sovereignty in these policy areas. Indeed, while market integration requires regulatory unification in order to harmonise trade-impeding national regulations, it does not imply delegation of administrative, fiscal or coercive capacities to the EU, thereby keeping integration comparatively non-intrusive. Moreover, by keeping aside distributive and identity interests, market integration has largely left mass publics disinterested, thus allowing for the emergence of the so-called permissive consensus (Hoogh and Marks, 2009). By contrast, the integration of national core resources of sovereign government (e.g. fiscal policy) at the supranational level requires high convergence and a substantial investment of fiscal, administrative and coercive capacity of Member States, who, however, are not always equally equipped to comply with the requests deriving from integration and willing to cede part of their sovereignty. Finally, as core state powers have a distributive function, mass publics are usually highly attentive to how resources are distributed, thereby creating conflicts between collective net-contributors versus collective net-recipients.

Therefore, the outbreak of the EU's polycrisis (Juncker, 2016) exacerbated the politicisation of the debate on EU integration and, by encroaching upon core state powers, brought to the surface new and simultaneous tensions both between and within Member States, which add up to traditional lines of conflict between left and right (Kriesi, 2016), thereby creating what Zeitlin and colleagues (2019) call the EU polycleavage. The emergence of this new conflict constellation put an end to the aforementioned permissive consensus and led to the so-called constraining dissensus, as decision-making on European integration 'entered the contentious world of party competition, elections, and referendums' (Hooghe and Marks, 2009, p. 7). At the national level, in fact, the EU became the object of increasingly polarised debates, divided electorates and volatile party competition. ${ }^{1}$ Political debate shifted therefore from politics without policy to politics against policy or even politics against polity (e.g. Brexit). At the same time, national party politics - by increasing the contestation in the interactions among EU actors - entered into the political debate at the European level, where a shift occurred from policy without politics to policy with politics (Schmidt, 2019). Indeed, politics of nationally partisan governments soon infected the decisions of the Council of the EU, while newly elected Eurosceptic members of the European Parliament influenced the parliamentary agenda. Similarly, independent institutions, 
such as the Commission and the ECB, were also indirectly affected by the increasing politicisation (Peterson, 2016). As argued by Schmidt (2019), however, politicisation at the EU level goes beyond direct national linkages and invaded the inter-institutional dynamics of EU-level decision-making. With the deepening of the European integration, in fact, EU actors became more interdependent and intensified their interaction in political struggles, not only over interest-based power, but also over which policy ideas are deemed most effective and legitimate.

To sum up, the politicisation of the debate over European integration led to increasing contestation and the emergence of new political divides. The restructuring of party competition at European and national levels around new divides and the pervasiveness of conflict dynamics at all political levels increase the difficulties in finding compromises for the adoption of new policies at the EU level. Indeed, the co-existence of multiple, multilevel conflict dynamics may become a source of political deadlock, whereby a blocking minority or criss-cross vetoes may hamper the capacity of the EU institution to solve urgent problems or advance common progress on a salient contested issue. Such a politics trap (Zeitlin et al., 2019) can explain the incapacity of EU actors to propose and pursue a social agenda and to agree on a legal and institutional framework that could prevent or compensate the negative externalities of the economic integration process on the proper functioning and maintenance of national welfare states.

Against this background, analysing the conflict dynamics that characterise the post-crisis debate on European integration in the field of social and employment policy can help us shed light on the reasons that have so far prevented the adoption of a comprehensive and ambitious social agenda and, at the same time, on the margin for manoeuvre or the spaces for the adoption of supranational policy in this area. Notably, in this book we look at the conflict dynamics that characterise the political debate at the supranational level, thus focusing on the positions assumed within the European Commission, Parliament and Council.

\subsection{CONFLICT DYNAMICS IN EU DECISION-MAKING: AN ANALYSIS OF THE LITERATURE}

How to interpret conflict dynamics at the supranational level has been an important topic for a sizeable part of the literature on EU integration (Costello and Thomson, 2013; Crespy and Gajewska, 2010; Hix et al., 2007; Kriesi, 2016; McElroy and Benoit, 2012). Academic debate has raged on the question of whether territorial or functional divides structure supranational politics. Earlier attention has been paid to the conflict dynamics within the European 
Parliament, while more recently, attention has been paid to the governments' positioning in the Council. This is because of the accessibility of parliamentary documents by the 1990 s, while publication of certain voting records and certain minutes from ministerial meetings of the Council occurred only after the 2000s.

\subsubsection{Voting Behaviour in the European Parliament}

The European Parliament (EP) represents a privileged locus to investigate political divides at the supranational level for at least two reasons. The first reason lies in the full access to parliamentary documents: draft reports; opinion reports; amendments tabled by MEPs; final compromise texts; records of the debates in parliamentary committees and in plenary; and roll call votes on each final vote on a resolution and, upon request of MEPs, also on single amendments. The second reason lies in the fact of the status of MEPs. Indeed, MEPs belong to the European Parliament Group (EPG), their national party delegation and their country of origin. This threefold agency makes MEPs respondents to different principals (and consequently different interests and values) and renders their positioning unique in order to grasp both functional and territorial divides over European issues.

Since the 1990s, several studies have focused on conflict dynamics and MEP positioning on European issues (Bakker et al., 2015; Bowler and McElroy, 2015; Crespy and Gajewaka, 2010; Hix and Høyland, 2013; Hix and Lord, 1997; Hix et al., 2007; Hooghe et al., 2002; McElroy and Benoit, 2012; Whitaker et al., 2017; Yordanova and Mühlböck, 2015). Among others, Hix and colleagues have consistently argued that, in the EP, the conflict is crystallising mainly into two functional divides, while national interests barely play a role in the actual voting. The first is 'classical' left-right divide, which mainly revolves around parties' positioning on economic issues. Parties on the economic left want government to play an active role in the economy. Parties on the economic right emphasise a reduced economic role for government: privatisation, lower taxes, less regulation, less government spending and a leaner welfare state (Bakker et al., 2015). The second line of conflict is 'pro- versus against further European integration'. In this respect, scholars argue that such a divide presents an inverted U-shape: party groups at both extremes are less favourable towards continued expansion of the competencies and authority of EU authority compared with 'centrist' parties, which are more in favour of centralisation of national competencies. According to the first model elaborated by Hix and Lord (1997), positions on further European integration and left-right contestation are independent of each other. While the former engages national sovereignty and mobilises territorial groups, which compete on where authority should be located, the latter involves the allocation of values among 
functional interests. Hence, party positioning on domestic issues and party positioning on European issues are orthogonal to each other.

A different position has been advanced by Hooghe and colleagues (2002) and recently also by Hix himself (Hix and Høyland, 2013). While recognising left/right and pro/against European integration as key dimensions in shaping the political debate at the EU level, Hooghe and colleagues (2002) argue that these two dimensions shape positioning on EU policies, but only in a limited subset of issues that are concerned with redistribution and regulating capitalism. Hence, the centre-left supports European integration in cohesion policy, social policy and environmental regulation, whereas the right supports market integration but opposes European re-regulation. In other policy areas, such as democratic freedoms and rights, other political divides explain the positioning of political parties. Notably, Hooghe and colleagues (2002) have highlighted the existence of a third line of conflict, which can be referred to as the distinction between GAL (Green, Alternative, and Libertarian) and TAN (Traditionalism, Authoritarian, and Nationalism) political factions. On the one hand, 'Libertarian' or 'postmaterialist' parties are in favour of the expansion of personal freedoms, for example, access to abortion, active euthanasia, same-sex marriage or greater democratic participation. On the other hand, 'Traditional' or 'authoritarian' parties often reject these ideas: they value order, tradition and stability, and believe that the government should be a firm moral authority on social and cultural issues. As argued by Hooghe and colleagues (2002), this new line of conflict (GAL-TAN) does not overlap but rather overshadows the existing left-right divide. Notably, in Western and Southern European countries, left-wing and liberal parties are usually associated with the GAL position, while right-wing parties are associated with TAN positions. By contrast, in the Central Eastern European countries, left-wing parties are TAN-oriented, because of their post-communist authoritarian nature, while right-wing parties are GAL-oriented (Bakker et al., 2015).

Finally, more recently, Crespy and Gajewska (2010) have proposed a fourth meta-cleavage to interpret MEP positioning. Notably, by focusing on conflict dynamics in the EP over the Services Directive, the authors unveil how national preferences (East vs West) played a significant role in shaping MEP positioning on the liberalisation of intra-European services. According to the authors, the Eastern enlargement has indeed changed the composition and ideological cohesiveness of European political groups so that the socio-economic issues, which have traditionally been associated with the left-right conflict, have become contentious issues on a territorial basis. At the same time, Crespy and Gajewska (2010) note how left-right orientation indeed plays a relevant role in shaping the position of MEPs. Therefore, they argue that the left-right divide and the East-West divide are not alternative vis-à-vis each other, but are instead combined and can be subsumed as a new liberals-versus-regulators 
cleavage, which combines contrasting economic interests and ideological positions and cross-cuts EPGs as well as country of origin.

Despite several differences, two main characteristics are shared by these divides (left versus right, pro versus against EU integration, GAL versus TAN and liberals versus regulators): on the one hand, they depict the EU's political space as mainly one- or bi-dimensional and, on the other hand, they tend to neglect or to diminish the territorial dimension of conflict. ${ }^{2}$ In so doing, however, they seem not to consider the recent multiple integration crises that have affected the EU, which instead suggests that a more complex conflict configuration at the EU level might have emerged in recent years (Hooghe and Marks, 2018, 2019; Hutter et al., 2016; Kriesi, 2016). In this regard, more recent studies on the new configuration of party politics on European issues at the national level showed how the politicisation of Europe in the national electoral arena has significantly changed in recent years. For instance, in their analysis, Hutter and Kriesi (2019) show how the inverted U-curve that explains extreme left-right parties' high contestation against EU integration is affected by a marked regional variety. Namely, contestation in Southern Europe mainly comes from extreme left parties against the austerity measures imposed by the new EU economic governance, while in North-West and Centre-Eastern Europe, extreme right political formations oppose any proposal for reform of the Schengen system after the refugee crises. At the same time, they argue that traditional left-right positioning has been restructured by the emergence of the immigration and Euro crises, most notably in Southern and North-Western European countries, while no significant changes concerned the Centre-Eastern European political space. These results suggest that also at the level of the EP, a more complex conflict dimensionality might emerge from the post-crises political debate, included in the field of social and employment policy.

In this respect, a reason that may explain why the traditional literature does not identify such a complexity of the political conflict over EU integration is methodological. Indeed, a large part of the aforementioned literature on conflict dynamics over European integration, with the exception of the work of Crespy and Gajewska (2010), relies on the quantitative analysis of roll call votes on final compromise texts voted in plenary (Bakker et al., 2015; Hix et al., 2003; McElroy and Benoit, 2012; Whitaker et al., 2017). This approach has shed light on the main divides which emerge from the voting behaviour within the EP, as well as the level of cohesion within the EPGs. Nevertheless, the roll call vote (RCV) analysis presents several shortcomings. Firstly, it considers only the final step, that is, the outcome, of the parliamentary debate, namely, the compromise proposal that is the result of months or even years of negotiations in the parliamentary committees, consultations with stakeholders and interand intra-institutional bargaining. Secondly, it overlooks the political rationale 
that accompanies voting behaviour in a case-specific circumstance, namely, it often does not distinguish RCV according to the policy issue under discussion (Finke, 2012; Hug, 2016; Yordanova and Mühlböck, 2015). Thirdly, RCV ignores the impact of certain factors, such as leadership or expertise, on party group cohesion (Bailer et al., 2009; Ringe, 2010). Finally, quantitative RCV analysis usually focuses on legislative resolutions voted in plenary, de facto ignoring all the other initiatives of the EP (e.g. parliamentary-initiative reports - so-called INI reports).

\subsubsection{Voting Behaviour in the Council}

As mentioned above, the academic literature on voting behaviour in the Council of the European Union is quite recent, as documents related to the Council's meetings have not been accessible for long, thereby making the Council an opaque institution. Although a large part of the decision-making still takes place behind closed doors, starting from the late 1990s and especially after the Lisbon Treaty, roll call votes, records, minutes of some meetings and issued statements of objections on Council final votes are now accessible and public. On the basis of the available documents and mainly relying on expert and elite interviews, several scholars have thus investigated the decision-making of the Council with the aim of understanding whether it is characterised only by territorial or also functional divides (Hagemann and Høyland, 2008; Mattila, 2004; Mühlböck, 2013; Toshkov, 2017; Veen, 2011; Wratil and Hobolt, 2019).

Mattila (2004) argues that traditional left-right and independence versus integration cleavages shape the political debate in the Council. Notably, while relying on voting records (RCV) of the Council, he argues that left-wing governments tend to vote less against the Council majority than their right-wing counterparts. However, 'if the government is a strong supporter of increased integration, its position on the left-right dimension does not matter much' (Mattila, 2004). Similarly, Hagemann and Høyland (2008) argue that voting patterns of governments and coalition formation in the Council are affected by the ideological affiliation of the incumbent government. Notably, they show that most of the governments tend to vote with other governments of the same or similar political affiliation and when governments change, the new coalition tends to find a coalition partner with governments with the closest political positions.

Not all scholars, however, agree on recognising the importance of ideological cleavages as explaining factors of government positioning within the Council. Using expert interviews, Thomson and colleagues (2004) reveal that coalitions among governments correspond with the partisan divide on only five out of 174 controversial issues. This is supported by Zimmer and colleagues (2005), who show that this dimension only offers "very weak support to the 
hypothesis that party lines or ideology determine the preference structure in the Council'. In this respect, by analysing the positions of governments relying on roll call votes, the analyses by Mattila (2004) and Hogeman and Høyland (2008) seem to suffer from an initial bias. This is because decision-making in the Council is still shaped by the so-called 'culture of consensus' (Heisenberg, 2005). National ministers tend to find a compromise on which everyone can agree, and 'no' votes are only justified if ministers can claim that the legislation at hand still significantly violates their interests. As argued by Hosli (2007), the consequence of this is that only a limited number of oppositional voices are recorded in the minutes, and the probability of a country voting 'no' is very low.

In order to overcome the shortcomings of the studies based only on RCV analyses, scholars have recently proposed to focus also on country position papers and the content of party platforms for EP elections (Veen, 2011); records and minutes of the Council meetings (Wratil and Hobolt, 2019); and governments' policy statements (Hageman et al., 2019). From these studies, it emerges that the conflict in the Council is redistributive rather than ideological and mainly pits net-receivers against net-payers of the EU budget. For instance, Veen (2011) argues that with the Eastern enlargement, a shift occurred from North-South to an East-West divide, but this did not change the dimensionality and nature of conflict in the Council, which remains mainly redistributive. Similarly, by examining the extent to which Member States' structural attributes explain the conflict within the Council of Ministers, Bailer et al. (2009) show that country-level redistributive interests shape the interactions considerably. On the contrary, the impact of ideological variables (e.g. left-right) remain marginal. Likewise, Wratil and Hobolt (2019), while relying on a new dataset that contains all the recorded minutes of the Economic and Financial Affairs Council (ECOFIN) meetings from 2010 to 2015, demonstrate the existence of a divide between net-receivers and net-payers on the size of the EU budget and a divide between debtor and creditor countries on how to reform the Eurozone.

\subsection{THEORETICAL FRAMEWORK}

The analysis of the existing literature on EU-level conflict dynamics unveiled some shortcomings that must be considered while elaborating our theoretical framework to investigate the specific political debate over Social Europe. Firstly, scholars describe the EU political space as mainly one- or bi-dimensional. Secondly, little attention has been paid to the context-specific dynamics, namely, to the political tensions and divides that might emerge in relation to a specific policy area. Against this background, an analysis of the conflict dynamics that characterise the debate on Social Europe must necessar- 
ily move from a context-specific analysis of the political obstacles, which has so far hampered the possibility to find an agreement on how to reform the EU towards a more social-sensitive agenda, while taking into account the recent developments related to the EU crises.

In this regard, Maurizio Ferrera (2017a) observes that the increasing difficulties of reconciling the social and economic dimensions of the European integration process have led to the emergence of a 'clash syndrome' in which old but exacerbated political divides overlap or intersect with new ones. Indeed, the multiple crises that affected the EU in recent years have generated new, durable dimensions of conflict, which mainly revolve around the defence of national political, social and economic ways of life. These crises acted as a critical juncture that transformed the pressures that have built up in past decades into political divisions around which political actors have repositioned themselves. However, contrary to Hooghe and Marks (2018), who describe the party system's reaction against 'external forces', such as the Euro crisis and the migration crisis, by referring to the creation of a new 'transnational cleavage' that subsumes the existing ones, Ferrera's 'clash syndrome' is the result of the combination of old and new political divides, which do not overshadow one another, but rather, combine and criss-cross. Notably, Ferrera argues that the political debate over EU social integration has been significantly affected by the EU polycleavage, which exacerbated existing tensions, which combined with existing tensions to result in an overlapping of four lines of conflict of a functional, normative and territorial nature:

- Market-making versus market-correcting priorities of the European (Monetary) Union;

- National social sovereignty/discretion versus EU law/conditionality;

- Intra-EU 'systemic competition' between high-wage/high-welfare EU countries and low-wage/low-welfare EU countries ('old versus new' or 'Western versus Central and Eastern' Member States); and

- Supporters versus opponents of fiscal stability or cross-national transfers (creditor versus debtor conflict).

The first two lines of conflict stem from the traditional divides between 'left versus right' and 'pro versus against (further) European integration'. However, their meaning and salience have been deeply affected by the recent legitimacy crises of the EU. Notably, the Euro crisis has reinvigorated the traditional left versus right conflict over the degree and type of public intervention in the economy. This divide rests on different visions and programmatic ideas about the overall mission of the EU and pits the supporters of a neoliberal project, centred on market-making, against a market-correcting oriented project, focused on a stronger social EU regulation. In this respect, many scholars have 
argued that the progressive weakening of market-correcting 'power resources' in the past three decades is to be interpreted as one of the main obstacles to the emergence of a strong social agenda at the EU level. For instance, Pierson and Leibfried argued as early as 1993 that the weaknesses of social-democratic forces (left-wing parties and trade unions) during the reinvigoration phase of the European Community (end of the 1980s and beginning of the 1990s) created space for what they call the 'anti-Social-Democratic consensus' in economic policy. Conversely, Corti and Vesan (2020) argue that the small window of the 'social-democratic return' at the turn of the 1990s, early 2000s, when the majority of the Member States' governments were ruled by social-democratic forces, gave a strong impulse to the relaunch of the EU social agenda. In 1997, the EES was launched, and the Amsterdam Treaty included a new Title on Employment and incorporated the Social Protocol. In 2000, the European Commission, the Parliament and the Council adopted a solemn proclamation on the European Charter of Fundamental Rights. Moreover, in the same year, the European Council launched the so-called Lisbon Agenda, which aimed to transform the EU into the most competitive and dynamic 'knowledge-based economy'. 3

The second line of conflict identified by Ferrera (2017a) refers to the divide between advocates of 'more power to Brussels' vis-à-vis defenders of domestic models and practices. The opposition between supranational centralisation and national sovereignty, more versus less integration, has long been a salient and constitutive dimension of the EU political space. At the core of this divide, there is what Leibfried and Pierson (1993) call the 'pre-emptive role of national welfare states'. As argued by Ferrera (2005), social policies are a polity-building factor - namely, they contribute to the definition of national boundaries, the creation of strong institutional bonding and the maintenance of national social legitimacy. Therefore, the transfer of social authority to the supranational level would imply changes of the boundaries at national, regional and local levels, depending on the multilevel organisation of each Member State. Clearly, the Commission and the Court are eager to extend their influence on social issues, because they see state-building opportunities in the struggle over a social dimension. However, against the possibility to reshuffle boundaries and bonding relationships between multilevel authorities and their citizens, Member States have several concerns and manifest their resistance. In this respect, Eurosceptic parties represent the epitome of the conflict between European integration and national (social) sovereignty, which turns into a conflict over the EU qua polity.

While the first two divides have a markedly functional nature, the third and fourth divides have a territorial one. Notably, the third line of conflict concerns the tensions around the issues of access to domestic welfare for other EU nationals, as well as labour mobility and social dumping. This tension is 
mainly characterised by the division between high-wage/high-welfare countries (old Member States, mainly Northern core countries) from low-wage/ low-welfare ones (new Member States, mainly Central and Eastern European (CEE)). A highly debated issue in this respect is, for instance, the posting of workers in the context of the provisions of services. On the one hand, old high-welfare Member States argue in favour of the protection of their domestic market from unfair competition and social dumping, and in defence of the autonomy in organising national labour and welfare systems. On the other hand, new low-welfare Member States support the freedom to access foreign markets for their service providers and argue in favour of the social protection of their posted workers. In this respect, Rasnača (2018) identifies four sets of interests when it comes to the debate over the posting of workers: (1) the old Member States' economic interests (i.e. protection of their domestic market from competition by foreign service providers); (2) the old Member States' social interests (i.e. autonomy in organising national labour and welfare systems); (3) the new Member States' economic interest (i.e. access to foreign markets for their service providers); and (4) the new Member States' social interests (i.e. protection of their posted workers).

Finally, the fourth divide identified by Ferrera (2017a) concerns the tensions around the issues of fiscal discipline and cross-national economic redistribution (fiscal transfer) and is linked to a potential conflict on solidarity and reciprocity that may concern issues ranging from anti-cyclical policy proposals to structural reforms of the EU's economic governance (Hutter et al., 2016). Such conflict is then made explicit in the contraposition between supporters of fiscal transfers and advocates of fiscal discipline. Notably, the advocates of fiscal discipline argue that violations of debt rules risk destabilising the European and Monetary Union (EMU) and, therefore, call for strict fiscal supervision. On the other hand, supporters of fiscal transfers identify the structure of the EMU itself as the cause of the crisis and therefore call for a permanent and comprehensive fiscal transfer system. In line with Lehner and Wasserfallen (2019), the divide between fiscal transfers' supporters and advocates of fiscal discipline is here seen as bi-dimensional. Namely, it is possible to support fiscal discipline without fiscal transfer (austerity: stabilisation through fiscal consolidation); fiscal transfer without fiscal discipline (un-conditionality: stabilisation through transfer); but also fiscal discipline and fiscal transfer (conditionality: compensating discipline with transfer); or neither of them (no fiscal commitments: integration sceptical) (Lehner and Wasserfallen, 2019). But what explains the position in favour or against fiscal transfers and risks sharing? According to Ferrera, this divide sets core Member States against peripheral ones and is rooted in both economic interests (creditors versus debtors) and highly entrenched cultural worldviews; and mainly runs from North to South. A similar distinction is recalled also 
by Johnston and Regan (2016) and Laffan (2016), who identify a territorial nature of the divide between two potentially conflicting sub-groups of countries: the creditor nations, mainly (old) Northern Member States (Germany in primis), versus the debtor nations, mainly Mediterranean Member States. This characterisation of the conflict between supports of fiscal consolidation and advocates of risks sharing and fiscal transfer, however, does not appear entirely convincing. Indeed, if public government debt would be the criteria for positioning in favour or against the creation of common fiscal stabilisers or the mutualisation of risks, one would not be able to explain the position of countries such as Ireland or Slovakia, with a debt to GDP ratio lower than the 60 per cent Maastricht threshold but still in favour of the creation of a common fiscal capacity. In this respect, it seems more convincing to look at the position of a country on issues of fiscal solidarity and debt mutualisation by considering its financial vulnerability. This can be measured by looking at the interest rates on long-term government bonds. Clearly these are highly sensitive to the sustainability of public debt and the current account balance of a country, which explain why the debtor-creditor divide largely grasps the conflict. Yet, looking at the interest rate on long-term government bonds allows to better explain why a country might be interested in profiting from the EU's more favourable borrowing conditions and thus is in favour of debt mutualisation and the creation of a common fiscal capacity. In addition, it is worth also considering the long-term government bonds' maturities that can explain the interest of countries, for instance, small economies in Centre-Eastern Europe that despite low interest rates cannot issue long-term bonds and thus would benefit from EU borrowing. ${ }^{4}$ Bearing this caveat in mind, in the remainder of this book we will still refer to this divide in terms of 'creditors vs debtors', the reason being to better link the fourth line of conflict to a consolidated academic debate and thus avoid the introduction of a new terminology.

As we observed, both the third and the fourth divide have a clear territorial nature. Yet it would be misleading to attribute to such territoriality a static connotation. Indeed the divide is not explained by the country per se but by the economic advantage that one country might derive either from more supranational regulation of cross-border labour mobility or from mutualisation of risks and cross-national fiscal transfers. On the one hand, such economic advantage can be explained in terms of protection from competitive internal devaluation based on wage compression and more favourable labour taxation. At the core of this divide there is what can be called the heterogeneity of socio-economic and cultural developments and national welfare systems within the Union, which makes any attempt to harmonise or integrate employment and social policies 'impractical'. On the other hand, the economic advantage can be explained in terms of more favourable interest rate or longer maturities of common EU long-term bonds and thus protection of most financially vulnerable countries. 
By adopting a more dynamic approach to territoriality we are able to capture the historical evolution of territorial conflicts. Indeed, while the emergence of the third and fourth divides is strongly related to the crises that affected the EU after the Eastern enlargement and the Great Recession, the roots of these conflicts are deeper. For instance, the wage differential represents a relevant problem since the creation of the Single Market, whereby labour cost becomes a competitive advantage factor for certain Member States. One can recall, for instance, that the Directive on the posting of workers was initially proposed in the early 1990s following the Rush Portuguesa ruling of the ECJ. On that occasion, as we will see in Chapter 4, the divide was not between Western and Eastern Member States but rather between the new Southern Member States (Portugal in primis) and the old Member States (notably France).

Overall, the difficulty in harmonising and coordinating heterogeneous socio-economic systems, together with the unwillingness of Member States to cede part of their social sovereignty, have been translated in the lack of an EU-level institutional framework to decide on social and employment issues. By 1993, Pierson and Leibfried had identified the fragmentation of political institutions as one of the main obstacles for the development of Social Europe. Notably, the authors argued that because most of the EU decisions in the field of social policy are adopted under the unanimity rule, the opposition of one member of the Council is enough to block any proposal, thus restricting the room for manoeuvre for the EU to the 'lowest common denominator' strategy. Across the years, this obstacle has been partially removed. Now, in fact, more EU decisions in the field of social policy are adopted under qualified majority voting and the ordinary legislative procedure, for instance, in labour mobility (including social security coordination), occupational health and safety and (partially) labour law and non-discrimination legislation. However, in several areas of social policies, decisions are still taken by the unanimity voting rule, such as, for instance, the harmonisation of national legislation in the field of social security and social protection. This institutional fragmentation has therefore further contributed to emphasising what can be called - paraphrasing the expression from Zeitlin and colleagues (2019) - the 'politics trap of Social Europe', namely, the political deadlock created by the activation of overlapping multiple splits on social and employment policies in the EU.

\subsection{RESEARCH QUESTIONS AND HYPOTHESES}

As anticipated in the introduction, two main sets of questions lie at the core of this book.

As regards the EP, the question is whether affiliation to an EPG or national affiliation shapes MEPs' voting on social and employment issues, and whether it is possible to distinguish between the line of national party delegations and 
that of the entire group of MEPs from the same country, no matter the EPG nor where the MEP comes from. Put differently, the first question reads as follows: What influences the positioning of MEPs on social and employment issues European political group membership, national party group membership or national affiliation?

This central question can be further disaggregated in a variety of sub-questions. For instance, are EPG membership and national affiliation two factors competing in defining the logic of voting behaviour, or do they identify the same voting patterns? If they compete, why do MEPs decide to position against their party group colleagues? And in that case, is that something that can be addressed to national party delegations in the EP or to national affiliation tout court? By answering these questions, we will be able to understand which conflict dynamics characterise political debate over EU social and employment policy in the EP. For instance, if the EPG affiliation prevails, we then can expect the emergence of a left-right or pro vs against (further) European integration divide, while, if the national membership prevails, we might expect the emergence of cross-party territorial divides.

As regards the Council of the EU, the question is whether Member State positioning on social and employment issues is influenced by national interests, governments' political affiliations to European political parties or their attitude towards the European integration. In this respect, the second research question reads as follows: How do national interests and European political parties' affiliations shape governments' positioning on social and employment issues? Do they follow their national interests, their political affiliation or their attitude towards the European integration process?

Also, in this case, this central question can be further disaggregated into a variety of sub-questions. For instance, is national government political affiliation affecting national interests in social and employment issues? Do European party groups play a role in shaping the position of their members before Council meetings? By answering these questions, we will be able to understand which conflict dynamics characterise political debate over EU social and employment policy in the Council. For instance, if the attitude towards the European integration prevails, we might expect a Member State to adopt a consensual approach and be more likely to accept a compromise. By contrast, if the national interest prevails, we might expect that a territorial conflict emerges whenever a controversial issue that directly touches upon national interests is discussed.

Drawing on the clash syndrome theory advanced by Ferrera (2017a), we expect the political conflict over EU social and employment policies at the EU level to be characterised by four lines of conflict of functional and territorial nature. Such lines of conflict do not overshadow one another, but instead they combine - and their combination can either turn into a political deadlock (what 
we called the 'politics trap of Social Europe'), which blocks any further progress in the European integration process in the field of social and employment policy, or open up the possibility for the emergence of new cross-party coalitions that might facilitate the adoption of new policy measures. Against this background, the salient question is how these four lines of conflict combine, and which factors might determine the prevalence of one or the other.

Based on the traditional literature on voting behaviour in the Parliament and the Council, we expect that the combination of these political divides depends on four main factors: the arena where the debate takes place; the actors involved; the issues under discussion; and the rules of the game.

Scholars who have investigated the EU as a bicameral political system have demonstrated that voting behaviour might differ significantly between EU institutions (Farrell and Héritier, 2004; Hagemann and Høyland, 2010). Indeed, ministers and MEPs are subject to different constraints within their respective institutions. On the one hand, ministers are subject to the logic of consensus (Heisenberg, 2005), whereby decisions, even when they are subject to qualified majority vote, tend to be adopted with the consensus of everyone. During the negotiations, concessions are granted to Member States, which are then expected to vote in favour of compromises. No-votes are only justified if ministers can claim that the legislation at hand still significantly violates their national interests. On the other hand, MEPs are mainly influenced by their parliamentary group (Hix et al., 2007) and tend to divide along functional tensions. As stressed by Mühlböck (2013), the different constraints to which MEPs and ministers are subject might lead to divergence in their voting behaviour. For instance, if the transnational group differs from the Council consensus, a minister, who has to seek compromise within the Council, and a MEP, who is acting as a loyal member of his/her transnational EP group, will be tempted to diverge from each other. Against this background, we hypothesise that voting behaviour on EU social and employment policy also differs according to the political arena where the debate takes place, as MEPs and ministers are subject to different constraints. More specifically, we might expect political divides in the Council - when they emerge - to be mainly driven by territorial factors rather than functional divides. By contrast, we expect transnational functional divides to prevail in the EP debate.

The second factor that affects the conflict constellations over EU social and employment policy is the actors involved in the decision-making. As regards the EP, several scholars have investigated the political cohesion of EPGs and demonstrated that it has significantly increased over the years (Hix et al., 2007; Yordanova and Mühlböck, 2015). Still, the influence of transnational groups on voting behaviour of their MEPs varies significantly from group to group. For instance, Bressanelli and colleagues (2015) show that centrist parties (i.e. the European People's Party (EPP), the Socialists and Democrats 
(S\&D) and the Alliance of Liberals and Democrats for Europe (ALDE)) invest more - and more successfully - in discipline, in coordination or in both. The reason why the EPP, the S\&D and the ALDE invest more than other EPGs in coordination and discipline is twofold. On the one hand, they need to signal credibility, since they traditionally form the 'grand coalition' in the EP which supports the Commission. On the other hand, all three EPGs have 'counterparts' from their party families in the Council (Hix and Høyland, 2013). By contrast, far left-wing and far right-wing parties, who do not take part in the 'Grand Coalition' and rarely have their counterpart in the Council, invest less resources in discipline and internal coordination. Against this background, we might also expect more cohesion among centrist parties on the debate over EU social and employment policy, while potential divides might emerge in the other parliamentary groups. Moving to the Council, actors involved in the political debate do affect the formation of supporting or opposing coalitions for further European integration. In this respect, Mattila (2004) demonstrates that pro-European governments tend to align with the majority in the Council, even when the final compromise agreement does not fully reflect their national interests. This is particularly true when it comes to smaller countries, whose weight in the Council-qualified majority vote is not sufficient to change the balance of power and political equilibria. Against this background, we can expect that on EU social and employment policy, pro-European governments are also more likely to align with the position of the majority in the Council, while Eurosceptic ministers are more likely to follow their national interests.

The third factor that affects the combination of political divides is the issue under discussion. In this respect, several scholars have argued that the dimensionality of conflict varies according to the policy proposal under debate. As regards the Parliament, for instance, Hooghe and colleagues (2002) show that centre-left parliamentary groups are more likely to support further European integration in cohesion, social policy and employment policy, whereas the centre-right groups support a market-building integration approach, with less regulation at the European level. Similarly, in the Council, despite the dominating logic of consensus, tensions are expected to emerge on most controversial policy proposals. As argued by Veen (2011), Member States tend to divide mainly on redistributive and integration (subsidiarity) issues. For instance, Lehner and Wasserfallen (2019) show that the political contestation over policies that concern the reform of the Eurozone is mainly territorial, pitting creditor countries against debtor countries. Against this background, we might expect that also in the case of EU social and employment policy, the political contestation may vary according to the specific issue under debate. Overall, we expect left-wing MEPs and ministers to be more supportive of further EU social integration, while right-wing MEPs and ministers will be less supportive of those issues. At the same time, we expect that when it comes 
to controversial issues, such as cross-national redistribution of resources or labour mobility and access to domestic welfare for other EU nationals, MEPs and ministers split on the basis of their territorial provenance.

Finally, the last factor that can affect the combination of political debate over EU social and employment policy is the so-called 'rules of the game'. In this respect, we might expect that different conflict dynamics can emerge depending on whether the debated policy proposal is a directive or a regulation. Indeed, while a directive requires Member States to achieve a certain result without dictating the means of achieving it, a regulation is a directly enforceable legal act. Therefore, we can hypothesise a higher resistance from Member States vis-à-vis the proposal to adopt a regulation than a directive in the field of social and employment policy, and therefore the emergence of a conflict between national social sovereignty versus EU law conditionality.

To sum up, based on the 'clash syndrome' theory and building on the traditional literature on voting behaviour in the Parliament and in the Council, we expect that the political conflict over EU social and employment policy is characterised by the overlapping of four lines of conflicts of territorial and functional nature, which criss-cross each other. Moreover, we expect that the overlapping of such tensions mainly depends on four factors: the arena in which the debate takes place; the actors involved; the issue under discussion; and the rules of the game. Notably, we expect functional divides to prevail in the parliamentary arena, and territorial tensions to characterise the political confrontation in the Council. We then expect pro-European, left-wing MEPs and ministers to be more in favour of further EU social integration than Eurosceptic and right-wing MEPs and ministers. Thirdly, we expect MEPs and ministers to divide on the basis of their territorial provenance, most likely on cross-national redistribution and fiscal stability policies, labour mobility and access to domestic welfare for other EU nationals. Finally, we expect the rules of the game, namely, whether the debated policy issue is a directive or a regulation, to affect the conflict constellation over EU social and employment policy.

\subsection{CASE SELECTION}

In September 2015, during the annual State of the Union speech, Jean Claude Juncker, the president of the EC, announced the adoption of the European Pillar of Social Rights (EPSR). ${ }^{5}$ The stated aim of this political initiative was to strengthen the social acquis of the European Union and foster a new upward convergence of social and employment rights primarily within the Eurozone. In particular, the Commission presented the EPSR as a reference framework intended to address the gaps in existing EU employment and social policy legislation and to rebalance the asymmetry between the economic and social 
dimension in the EMU. To this end, the Commission identified 20 common principles and rights divided into three main categories: (i) equal opportunities and access to the labour market; (ii) fair working conditions; and (iii) social protection and inclusion. ${ }^{6}$

According to the Commission's documents, the Social Pillar fulfils a twofold objective. As a political strategy, the Pillar seeks a renewed consensus on the EU, strongly delegitimised by the migrant and sovereign debt crises, EU-induced austerity and its severe social consequences at the national level. As a policy initiative, the EPSR mainly serves to restate certain principles and rights already enshrined in the EU Treaties and secondary legislation, update the so-called 'social acquis', reinforce the monitoring and coordination of social and employment issues in the context of the European Semester and strengthen the redistributive dimension of the EU budget. Put differently, the Social Pillar's 'strategy' is essentially based on a threefold approach: firstly, where possible, the enactment of secondary legislation in order to set certain standards in the field of working conditions or social protection (regulatory area); secondly, the use of the existing instruments for macroeconomic convergence in order to ensure the application of the necessary measures (coordination area); and thirdly, financial support through the use of available EU funds (redistributive area) (for further details on each initiative, see Chapter 3).

As a comprehensive initiative which touches upon several policy areas with the explicit aim of updating the EU social acquis and relaunching the EU social dimension, the Social Pillar therefore offers a unique opportunity to investigate the EU-level political conflict in the field of social and employment policy after the outbreak of the EU polycrisis. Indeed, in the framework of the Social Pillar, as we will see in Chapter 3, several initiatives have been adopted in the areas of EU legislation, social policy coordination and the EU budget. This provides access to invaluable material to trace the political debate and the dynamics of the conflict on EU social integration. Against this backdrop, this book proposes a collection of four case studies, which focus on four initiatives related to the Social Pillar, which I consider as extremely interesting case studies to investigate what can be called the politics of Social Europe.

Firstly, we investigate the political debate in the EP on the resolution on the Social Pillar prepared by MEP Maria João Rodrigues. The aim of this chapter is to offer an overview of the multiple conflict dynamics that emerge on the Social Pillar, as an umbrella initiative that touches upon different social policy areas: legislative, coordination and redistributive. Indeed, as we will see more in detail in Chapter 3, the parliamentary report prepared by the S\&D vice president Rodrigues is the only comprehensive text that contains all the legislative proposal that the Commission presented to implement the Pillar and goes even further by proposing new concrete measures, which were not in the 
Social Pillar's implementation roadmap of the Commission. A focus on the EP debate and vote will offer the unique possibility to empirically test the validity of all four lines of conflict identified in the theoretical framework, by looking at the positioning of MEPs on multiple policy issues in the field of EU social and employment policy, and at the same time identifying the most salient and controversial issue on which EPG cohesion holds or breaks. Moreover, by touching upon multiple issues, the debate on the EP report on the Social Pillar will allow us not only to trace the political divides that emerge on each issue but also to understand which divides prevail in the MEPs' final vote. In so doing, we will be able to understand the complex political constellation that emerges in the EP arena, between parliamentary actors (MEPs) on an exhaustive range of policy issues in the EU social and employment field.

Once we have analysed the conflict dynamics in the EP on the Social Pillar, we focus on two initiatives, which were debated under the Juncker Commission, namely, the revision of the posting of workers and the proposal to create a common fiscal capacity for the EMU, notably in the form of a European Unemployment Benefit Scheme. The selection of these two initiatives is related to the fact that they touch upon the most controversial issues which we identified in our theoretical framework and where we expect the emergence of territorial divides both in the Parliament and in the Council. Notably, as argued above, the logic of consensus that prevails in the Council does not hold when ministers and national representatives debate on controversial issues that directly touch upon their interests. Therefore, by selecting these two case studies, the objective is to investigate the conflict constellation on two policy proposals that directly relate to the issues of labour mobility/access to domestic welfare and cross-national redistribution/fiscal stability, where we expect the emergence of territorial divides.

On the one hand, the focus on the revision of the Posting of Workers Directive will allow us to analyse more in detail the conflict dynamics that emerge on issues concerning labour mobility, social dumping and fair competition. By focusing on this initiative, we will be able to better grasp the specific political divide between high-wage/high-welfare and low-wage/low-welfare EU countries and how this political tension relates to other dimensions of political conflict. Notably, we trace the positioning in the EP and in the EPSCO Council. Moreover, we compare the debate over the revision of the posting of workers with the debate over the Monti II Regulation and the Enforcement Directive, with the aim to understand whether and how the positioning of the European Commission and the switch in the rules of the game (from the proposal for a regulation to a revision of a directive) affect the positioning of political actors and influence the coalition formation.

On the other hand, the analysis of the political debate on the proposal for a European Unemployment Benefit Scheme (EUBS), and more in general on 
the proposal to create a common fiscal capacity instrument to absorb asymmetric shocks at the EU level, will allow us to better grasp the conflict dynamics over issues concerning cross-national redistribution and fiscal stability, thus focusing on the second new lines of conflict that emerged in the aftermath of the Euro crisis, namely, the divide between supporters and opponents of fiscal stability and cross-national transfers. As in the case of the posting of workers, we will compare the positioning of the Parliament and the Council, vis-à-vis the proposal advanced by the European Commission.

Finally, the fourth selected case study investigates the role of politics in the orientation of the Country Specific Recommendation addressed to Member States in the framework of the European Semester. Notably, we analyse whether and how the Juncker Commission contributed to the so-called socialisation of the Semester. Contrary to the previous three case studies, here the focus will be mostly on the role played by the Commission and on how its position determines the orientation of the Semester.

\subsection{RESEARCH STRATEGY}

To investigate the first three case studies, this book adopts a primarily qualitative approach. The research design is largely built on a criticism of the many quantitative studies that have already been conducted in this area. Moving from the EP, as argued in Section 1.3 of this chapter, the traditional literature on voting behaviour in the EP has relied on quantitative analysis of a large-n set of roll call votes. This approach, however, presents several shortcomings, the most significant being its incapacity to grasp the rationale behind MEPs' political positioning (see Cicchi, 2016). Indeed, by focusing on the final vote, this literature completely bypasses the dynamics of conflict and is not capable of identifying the issues on which tensions emerge. Moreover, it ignores the real political parliamentary debate which does not happen in the plenary where the final RCV takes place, but rather, in the Parliamentary committees. Indeed, EP committees are the arena in which MEPs discuss policy proposals (Whitaker, 2011). The committees of the EP have three main functions: to draw up, amend and adopt both legislative proposals and reports proposed on their own initiative. Each report is first debated in the committee, and, after a formal vote, it then goes to the plenary for the approval of the final position. Reports are compiled by a rapporteur, who is indicated by the chairman of the committee, after consultation between and within EPGs (see Yordanova, 2011). The rapporteur is responsible for preparing the report and presenting it on behalf of the EP and the committee during the negotiations with the Council and the Commission. After the rapporteur presents the draft report, each MEP of the committee is entitled to table amendments to the draft text proposed. Amendments can be presented by an MEP, by a group of MEPs or by one MEP 
on behalf of a political group. Usually, the third kind of amendments are tabled by the so-called shadow rapporteurs. ${ }^{7}$ Finally, it is important to stress that amendments in parliamentary committees are not tabled on the whole report, but rather, on each single part of the report. Notably, we can identify three main components of an EP report: citations, recitals and articles. Citations are the first part of the report where there are the references to the legal basis of the text. Recitals consist of general assessment and premises that justify the following articles. Articles are the core of the report, where we find concrete statements on the policies to be adopted. Each article focuses on a particular policy issue. This means that within a single parliamentary report, we can find more sub-issues, on which MEPs can have different positions.

Scholars who have studied the parliamentary activity in the EP committees have mostly focused on the topic of membership of EP committees and the assignment of leadership positions and rapporteurship (Benedetto, 2005; Bowler and Farrell, 1995). Some studies have researched the extent to which national parties use the committees' system to further their policy goals (Whitaker, 2011). Other scholars have analysed the amendments tabled by MEPs on the final compromise text voted on in a committee and presented in plenary (Crespy and Gajewska, 2010; Yordanaova, 2011).

While all these studies shed light on specific aspects of the parliamentary activities in EP committees, none of them has investigated political conflicts within the EP committees. Most of these studies, indeed, have analysed the parliamentary activities in the EP committees, ex ante, in assignment of roles or rapporteurship, or ex post, in relation to MEPs' positioning on final vote. However, they all ignored the MEPs' positioning in the debate within the EP committees, after the assignment of rapporteurship and before the final vote on a report. In this respect, no research has been conducted, at least to my knowledge, on the amendments tabled by MEPs in EP committees. However, these amendments are the core of the EP committees' activity and are a unique source of information to investigate political positioning in the EP. Indeed, as explained above, each tabled amendment is signed by one or more MEPs or by an MEP on behalf of his/her political group. Amendments can either propose to further strengthen the proposed text, change the wording or delete certain parts or the entire text. A justification can also be added explaining the reason for an amendment. Finally, amendments can be tabled that also propose to add a new part to the report, if an MEP deems the draft text to be incomplete. The rapporteur is then in charge of scrutinising all the tabled amendments and proposing compromises that take into account the concerns and proposals raised by the other MEPs. Each compromise proposal is then voted on in the committee, while those amendments, which are not included in the rapporteurs' compromise text, are voted on separately. Votes on each compromise or single amendments are usually by a show of hands, unless an MEP on behalf of his/ 
her EPG asks for an RCV. The vote on the final text is always conducted by RCV. Against this background, amendments tabled in the parliamentary committee are a unique source of information that show the detailed positioning of MEPs on policy proposals before compromises are advanced. Therefore, an analysis of these amendments can unveil information on MEPs' (actors) positioning and allow us to understand the reason underlying the political confrontation in the EP (arena). ${ }^{8}$ Moreover, since amendments are tabled on each specific part of a parliamentary report, we will be able to identify and distinguish amongst the proposals (issues) on which MEPs position themselves. By contrast, should we rely on RCV analysis alone, this would completely ignore the core of the committee's political debate, and, most importantly, it would not allow us to understand the dynamics of the conflict underpinning the negotiations. Indeed, since the RCV is on the final (if any) compromise text, many MEPs will likely vote in favour.

Against this background, the strategy adopted in this book to investigate the political conflict within the EP consists of carrying out qualitative analysis of the amendments tabled in the committee in charge of certain dossiers. Notably, we first present the initial draft text on which MEPs table their amendments. Secondly, we qualify each tabled amendment, by attributing to each of them the EPG membership and the national origin of the MEP(s) who tabled it. Thirdly, we classified the amendments by looking at how they proposed to change the original draft resolution. In detail, we distinguish the amendments in favour of the rapporteur's proposal (for example, introducing only minor changes or adding parts that reinforce the original proposal) and those against (such as deleting the original paragraph or changing some parts to weaken its original meaning). On this basis, we create a matrix with all the amendments tabled either in favour of or against each part of the report (citation, recital and article). Fourthly, we identify in the matrix each controversial part of the report (issue), where MEPs tabled amendments both in favour of or against the draft proposal and analyse what kind of divide emerges from the amendments' content. Fifthly, we analyse - where possible - the compromises proposed by the rapporteur and the final RCV on the text both in the committee and in the plenary. The analysis is also accompanied by the presentation of the justification statements presented by MEPs and their declarations in the committee and plenary. Finally, the empirical findings were triangulated with elite and expert semi-structured interviews with key policy makers involved in the policy-making process. Table 1.1 presents how many amendments were analysed in each chapter and the interviews with the MEPs involved.

In terms of the methodology adopted to understand Member State positioning in the Council, as stated in Section 1.3 of this chapter, the traditional literature has mainly focused either on official voting records (Hagemann, 2007; Hagemann and Høyland, 2008; Mattila, 2004) or expert interviews 
Table 1.1 Number of amendments and interviews per parliamentary report

\begin{tabular}{l|l|l}
\hline Parliamentary report & \multicolumn{1}{l}{$\begin{array}{l}\text { Number of amendments } \\
\text { tabled in EP committee }\end{array}$} & $\begin{array}{l}\text { Number of } \\
\text { interviews }\end{array}$ \\
\hline Report on the European Pillar of Social Rights & 1119 amendments & 7 \\
\hline Report on Enforcement of the Posting of Workers Directive & 883 amendments & 3 \\
\hline Report on the Revision of the Posting of Workers Directive & 523 amendments & 3 \\
\hline $\begin{array}{l}\text { Report on Strengthening the social dimension of the Economic } \\
\text { and Monetary Union (EMU) }\end{array}$ & 124 amendments & 3 \\
\hline $\begin{array}{l}\text { Report on a budgetary capacity for the Eurozone (and } \\
\text { establishment of European Unemployment Benefit Scheme) }\end{array}$ & 836 amendments & 4 \\
\hline
\end{tabular}

(Thomson et al., 2006; Thomson et al., 2012; Wasserfallen et al., 2019) to reconstruct political positioning. In the first case, however, given the 'culture of consensus' that characterises the Council voting behaviour (Heisenberg, 2005), RCV analysis does not allow us to reconstruct the political debate that occurs in the Council configuration. National ministers, in fact, tend to find a compromise on which everyone can agree, and 'no' votes are only justified if ministers can claim that the legislation at hand still significantly violates their interests, which implies that 'no' votes are very rare (Hosli et al., 2007). These consensual votes thus give relatively limited information about government positions during the negotiations. In the second case, the drawback of relying only on interviews is that these must be conducted in close temporal proximity to negotiations in the Council to reduce the potential problem of post-diction bias. Against this background, in order to reconstruct the position of national governments, we rely on a combination of multiple, complementary sources of information to unveil the national governments' positions on the policy proposals under discussion. Firstly, we look at videos of public sessions of Council configurations. Indeed, in June 2006, the European Council decided to make a large proportion of its legislative deliberations in the Council open to the public. From then on, webcasts of the open deliberations were made available on the Council's website (video.consilium.europa.eu). Since the adoption of the Lisbon Treaty in December 2009, when Council configurations deliberate or vote on draft legislative acts or discuss presidency work programmes and other questions of strategic relevance, they have to meet in public. At the beginning of each Council configuration's meeting, the chairman (namely, the minister of the country that holds the presidency of the Council of the EU) illustrates the subject of discussions, and, if negotiations are already advanced, he/she illustrates the controversial issues on which Member States have still to find an agreement. One or more documents are usually circulated before the meeting among ministries. If the object of discussion is a legislative text, the 
presidency generally presents a proposal for a compromise text. If the object is a general debate on a non-legislative proposal (e.g. a Commission communication), the documents distributed usually contain questions for the debate. Once the chairman has introduced the object of debate, the Commission takes the floor to explain its position. After that, Member States intervene to express their position and/or their declaration of vote, which can be also accompanied by an explanatory policy statement. The advantage of relying on records of Council meetings is that ministers' or their delegates' (actors) speeches during these meetings (arena) are technical and forthright, and allow us to understand in detail the proposals (issues) on which - and the reasons why - Member States are divided. Moreover, videos of public sessions of the Council are not affected by post-diction bias and can be analysed at any point in time. Finally, as stressed by Wratil and Hobolt, Council's videos 'also provide the most direct measurement of actor positions, free of any information filters applied by experts or officials' (2019, p. 514). To study the Council's video, we manually transcribe the records of the ministers' or their delegates' speeches during the debate and qualitatively analyse them, by classifying them according to their positioning vis-à-vis the proposed text of the Commission or the compromise text offered by the presidency. Notably, we first list the controversial issues under debate. As stated above, the controversial issues are explicitly mentioned by the Council's presidency at the beginning of each meeting. Secondly, since in each intervention a minister touches upon several issues, we divide the speech into multiple parts and select only the statements that refer to the controversial issues identified above. Thirdly, we classified these statements by looking at how they proposed to change or maintain the compromise proposal. In detail, we distinguish the statements in favour of the presidency's or Commission's proposal and those against. On this basis, we create a matrix with all the ministers' statements on each policy issue and then identify the tensions that emerge.

The second source of information we use to trace the positioning of Member States in the Council is - where available - reasoned opinions sent by national parliaments when they deem that a Commission's proposal violates the principle of subsidiarity. These documents are extremely informative about the concerns that Member States have on certain issues and offer a detailed description of the reasons why a national parliament opposes a certain policy proposal.

The third source of information is - where available - national position papers. In this respect, the Commission, when launching a new initiative, may ask Member States to present national contributions to the debate. This is the case, for instance, of the consultation on the Five Presidents' Report on the reform of the Economic and Monetary Union. As we will argue in more detail in Chapter 5, each Member State was invited to submit a national con- 
Table 1.2 Documents analysed and interviews conducted per initiative

\begin{tabular}{l|l|l|l}
\hline \multicolumn{2}{l}{$\begin{array}{l}\text { Initiative debated } \\
\text { or ECOFIN meetings }\end{array}$} & $\begin{array}{l}\text { National Position Papers } \\
\text { and/or national parliament } \\
\text { reasoned opinion }\end{array}$ & \multicolumn{2}{l}{ Interviews } \\
\hline $\begin{array}{l}\text { Enforcement of the Posting of } \\
\text { Workers Directive/ Monti II } \\
\text { Regulation }\end{array}$ & 7 EPSCO & 12 reasoned opinions & 3 \\
\hline $\begin{array}{l}\text { Revision of the Posting of Workers } \\
\text { Directive }\end{array}$ & 10 EPSCO & 15 reasoned opinions & 2 \\
\hline $\begin{array}{l}\text { Communication on Social } \\
\text { Dimension of EMU }\end{array}$ & 2 EPSCO & - & 4 \\
\hline $\begin{array}{l}\text { Five Presidents' Report - Reform } \\
\text { EMU Package }\end{array}$ & 1 ECOFIN & 42 position papers & 2 \\
\hline
\end{tabular}

tribution on the basis of a set of questions provided by the Commission and a draft text that identified the areas of intervention in the short and long term to reform the EMU. These documents are highly informative on the position of Member States and allow us to understand the underlying rationale behind each Member State's support or lack of support to any policy proposal.

Finally, the empirical findings were triangulated with elite and expert semi-structured interviews, with key policy makers involved in the policy-making process. Table 1.2 summarises the sources of information used to trace the position of the Member States in the two case studies (revision of the posting of workers and creation of an unemployment benefit scheme), where we analysed the positioning of Member States in the Council.

Finally, from a methodological perspective, Chapter 6 is somewhat of an oddity in this book, since its objective is not to trace MEPs' and Member States' positioning, but rather, the impact of the political pressure exerted by the Commission to orient the social and employment Country Specific Recommendations (CSRs) in the European Semester and trace the evolution of social CSRs from the inception of the Semester until the 2019 cycle. In this respect, this chapter refers to another strand of literature according to different methodologies. Notably, as we shal argue more in detail in Chapter 6, we adopt a qualitative approach to analyse the orientation of social and employment recommendations addressed to Member States, while proposing a new and original coding scheme to classify them. Drawing insights from Hemerijck's classification of welfare policy paradigms (Hemerijck, 2017), all social policy prescriptions were categorised into three groups: social-retrenchment; social-investment; and social-protection recommendations. A total of 1076 recommendations were classified. Finally, the empirical findings were triangulated, with 19 in-depth semi-structured interviews with experts and elites 
within the European Commission, the Parliament and the Council, and among social partners and non-governmental organisations.

\section{NOTES}

1. Three interrelated phenomena describe the concept of politicisation at the national level: (i) European issues increasingly get political salience in national public sphere; (ii) mainstream (centre-left and centre-right) parties lose public consensus and have difficulties in coping with increasing divides; (iii) rise of populist and Eurosceptic parties that give voice to discontent.

2. Except for Crespy and Gajewska (2010).

3. In this period, new modes of governance based on the so-called Open Method of Coordination were introduced, thus extending the potential influence of the EU institutions in the domain of employment and social policies, beyond the strict EU legislative competences (Zeitlin et al., 2005).

4. I would like to thank Frank Vandenbourcke on this point.

5. In this book, we will refer to the European Pillar of Social Rights by its acronym - EPSR - and its shorter names: 'Social Pillar', or simply 'the Pillar'.

6. The 20 principles are accompanied by various types of legislative and non-legislative initiatives. For further details on the EPSR, see Chapter 2.

7. Shadow rapporteurs are MEPs selected from each political group (one shadow rapporteur per group) and have the task to follow the report prepared by the rapporteur and table amendments on behalf of their group. Clearly, there is no shadow rapporteur for the EPG to which the rapporteur belongs (e.g. on the EP report on the Social Pillar, S\&D MEP Maria João Rodrigues was the rapporteur. Therefore, the S\&D did not have any shadow rapporteur).

8. This statement relies on an assumption that indeed needs clarification. The assumption is that the deputies of the European Parliament not members of the committee in charge of drafting and voting a certain parliamentary report will maintain the same position as their fellow colleagues when voting in plenary. Such assumption is theoretically and empirically justified by the work of Nils Ringe, Who Decides and How? Preferences, Uncertainy, and Policy Choice in the European Parliament. In his book, Ringe focuses on what he calls perceived preference coherence in MEPs' voting behaviour, while looking at MEPs' positioning in EP committees. According to Ringe, EPG cohesion in RCV voting is to be explained neither in light of party discipline (Hix et al., 2007) nor legislators' shared preferences. On the contrary, Ringe argues that EPG and especially national parties' cohesion within the EP is to be explained in light of MEPs' lack of resources and expertise to make fully informed decisions on most policy proposals, which leads them to adopt the positions of those expert colleagues in the responsible legislative committee whose preferences over policy outcomes they perceive to most closely match their own. Put differently, non-expert MEPs (i.e. those not members of the committee in charge of a specific report) adopt the positions of their expert colleagues in the responsible committee whose preferences they believe most closely match their own. This is based on the assumption that these positions resemble what they would favour if they possessed the resources and expertise required to truly judge the content and likely implications of a specific policy proposal. Ringe labels this mechanism explaining perceived preference coherence (PPC). The reason why non-expert MEPs rely on their expert colleagues is that it is highly 
unlikely that legislators have full content expertise (i.e. technical knowledge of the issues under negotiation) and preference information (i.e. knowledge of other actors' preferences and political constraints) on every single report discussed in the EP. Therefore, non-expert MEPs follow the preference of their fellow experts in the responsible committee. But who are those experts? Ringe argues that experts are, firstly, fellow national party colleagues in the responsible committee and, secondly, colleagues from the same European Parliamentary Group. For instance, an Italian MEP of the Democratic party will firstly follow the line of his/her colleague(s) in the responsible committee of a certain report and, at the same time, if they are not within EPG divisions, he/she will also follow the line of the colleagues of his/her EPG. Since national delegations belonging to the same EPG do coordinate within the EP committee before starting negotiations with other EPGs (each EP committee has a coordinator for each EPG), the position of national party delegation and related EPG position often coincides. This explains the high degree of cohesion within EPGs in EP committees which is then replicated also in the plenary vote. This said, this cohesion should not be taken for granted. As we will see in this book, national party delegations within the same EPG are not always able to find a compromise position within EP committees. When this happens, then, the same division is replicated also in the plenary RCV. This further confirms that non-expert MEPs do vote according to following the opinion of their expert colleagues, namely, their national party colleagues, in responsible EP committees. 